\title{
EXPERT-BASED EVALUATION OF DIGITALIZATION AND MASS CUSTOMIZATION IN THE BALTIC NON-LIFE INSURANCE ONLINE PLATFORMS
}

\author{
Gedas Baranauskas \\ Mykolas Romeris University, Lithuania \\ Agota Giedrẻ Raišienè \\ Mykolas Romeris University, Lithuania
}

\begin{abstract}
The expansion of online distribution platforms illustrates how non-life insurance companies are shifting to digital and customized personal line insurance products. This research extends previous investigations on digital insurance transformations and customization trends in the European and Baltic markets. Expert-based evidence on predominant as-is features in existing non-life insurance online platforms and evaluation on a practical spread of 3 capabilities of the Mass Customization concept are key research outcomes. Results reveal that neither the Mass Customization concept and its capabilities nor combinations with digital and personalization solutions are sufficiently widespread within the Baltic non-life insurance market. Results of the digitalization evaluation indicate that the level in the Baltic non-life insurance sector is between Satisfied and Rather Good and is equal to the level of service provider's preparation for digital solutions. However, it is behind the actual needs of end-users. Findings show that standardization is a predominant as-is feature in the Baltic non-life insurance online platforms.
\end{abstract}

Keywords: digitalization, mass customization, standardization, online insurance, platforms, Baltics.

DOI: http://dx.doi.org/10.15549/jeecar.v8i2.644

\section{INTRODUCTION}

The real-time experience of the COVID-19 pandemic shows a surprising and enterprisewide influence on the global economy, including significant consequences to business models of financial institutions (Chang, Survant, Walch \& Woo, 2020; Schilirò, 2020). This prolonged, wavy health crisis has had both internal and external impacts on financial institutions such as insurance companies by causing them to rethink an existing product's business logic, technical architecture, and organizational culture. Changing customer behavior has triggered the development of a platform-based business model and architecture that are 
reflected in new insurance products, more personalized, usage-based insurance services, and the enablement of openness and cocreation-based processes, resource integration, and orchestration (Wiesböck, Matt, Hess \& Li, 2017; Warg, Zolnowski, Frosch \& Weiß, 2019; Schilirò, 2020). High competition among traditional and virtual peers and intensive development of modern information and communication solutions have already been noticed (Łyskawa, Kędra, Klapkiv \& Klapkiv, 2019; Zarina, Voronova \& Pettere, 2019; Baret, Celner, O'Reilly \& Shilling, 2020).

The main research problem arises from practice, where a high penetration of e-services and its rapid increase has become a global standard in the financial sector and has had a strong focus on the digitalization strategy of insurance companies. However, insufficient alignment and a vague spread within e-service end-users at the operational level have been identified. Studies on digital maturity indicate that the current status as-is is considered as a technological breakthrough and a pre-stage towards a full digitalization of the insurance industry (Mustafina, Kaigorodova, Alyakina, Velichko \& Zainullina, 2020). Researchers such as Wiesböck et al. (2017), Klapkiv, Lyubov and Zarudna (2018), Voronova et al. (2018), Zarina et al. (2019), and Shubenko (2020) have made analyses of specific insurance value chain parts, for instance, strategic management, claims operations management, sales distribution, and insurance product digitization (Baranauskas, 2021). It is important to note that these researchers are limited by the origin country or region, for instance, Germany, Poland, Ukraine, Latvia, three Baltic countries. Bohnert, Fritzsche and Gregor (2019), Łyskawa et al. (2019), and El Arif (2020) have selected a more comprehensive focus on digital agendas and their implementation and development. Moreover, financial investments from insurance organizations and possibilities of online distribution in Europe also have been analyzed by the authors mentioned above (Baranauskas, 2021). The analysis of prevailing studies suggests that researchers mostly concentrated on digitalization, information and data, communication technologies and the behavior of insurance end-user researchers. These topics have been analyzed in separate silos at a high level, mostly oriented to specific insurance types (life and non-life insurance), regions (countries from Western or Eastern Europe, USA, etc.), product groups, or insurance service types in the insurance-specific value chain. Therefore, this particular research aims to contribute by extending and compiling previous scientific investigations focusing on combined analysis of digital insurance transformations and customization outcomes and identifying the asis status of the insurance digital platform business model in the Baltics. The expected research results of expert-based evidence on predominant as-is features and an evaluation of the spread of the Mass Customization capabilities in existing Baltic non-life insurance online platforms are summarized. To investigate this situation, the following questions have been raised:

1.What is the digitalization level in the Baltic non-life insurance online platforms?

2.What is the predominant as-is feature in Baltic non-life insurance online platforms?

3. How are three key Mass Customization capabilities spread in Baltic non-life insurance online platforms?

From the methodological point of view, this research follows a triangulation logic of a combination of simplified Fuzzy and Likert logic questionnaire techniques and embedded, descriptive case studies. The structure of the paper is composed of five sections and subsections inside. The first section has two subsections, which introduce the topic with a literature review on problems and theoretical background in the context of modern insurance research, insurance-specific value chain digitalization, and Mass Customization concept application. The second section covers a research methodology and methods while the third section contains two subsections, where a survey methodology and key findings of the expertbased online survey are presented. The fourth part provides a discussion on research limitations and future directions, and the fifth concludes the findings. 


\section{LITERATURE REVIEW}

Discourses of Digitalization and Mass Customization Studies in the Insurance Service and Platforms

Digitalization, including digitization, digital transformation, digital technology, online insurance, or digitalization of insurance in combinations of urbanization, individualization, and population aging receives much scientific interest in the modern insurance research field (Klapkiv et al., 2018; Bohnert et al., 2019; Łyskawa et al., 2019). Researchers of the insurance field carry different definitions at the semantical level, where one side stands for an interpretation of the expression digitization of insurance that is limited to implementation of Information and Communication technologies into insurance in the context of digitalization processes (Stoeckli, Uebernickel \& Brenner, 2016; Cappiello, 2018). This position is partly supported by results of practical analyses illustrating that the main effects of digital transformation in the insurance industry are recognized in divided parts as personal line insurance products, distribution channels, or back-office operations. Insurance digitization in a narrow, technology-based approach was more analyzed in the late 2000s and 2010s

A more holistic and combined technologicalmanagement approach to the digitalization of insurance spread both at a theoretical and practical level only in the past decade. It was noticed that effects and an influence of digital insurance technologies application cannot be considered by using an isolated semantical interpretation or division into the following subcategories: internally oriented technical solutions, which support insurance business at the operational level, and externally oriented technical solutions for interaction with an enduser and partners and support of their journey (Nicoletti, 2016; Bohnert et al., 2019). Here, the key research gap of modern insurance investigation can be identified by splitting several points. First, a more comprehensive analysis including variables from primary and supporting activities of the insurance-specific value chain as well as their combinations with digitalization and Mass Customization and Personalization domains are needed. This standpoint reveals the full potential and influence of digital technologies in insurance and allows for the prediction of digital development directions in the insurance industry. It is also confirmed by practical trends in recent years, which illustrates insurance purchasing being not a linear process or a homogenous value chain anymore, and a comprehensive holistic and digital approach is required (Albrecher et al., 2019; Bohnert et al., 2019). Second, insurance digitization and digitalization as a research domain receives much interest in the insurance field and is reflected in different forms in all primary activities, but lacks deeper investigation in Human Resource Management, Controller, Legal or Public Relation activities. The majority of reviewed researchers selected a holistic approach by evaluating digitalization from general management (strategical) application, IT infrastructure, or combined-cross functional approach points of view.

Figure 1 summarizes the directions of recent theoretical analyses and presents a conceptual framework for further investigation.

Figure 1 illustrates recent directions of insurance digitalization analysis and stands as a conceptual framework with assumptions on an application of three key Mass Customization capabilities in primary and support activities of the insurance-specific value chain. It also can be a framework for further investigation in this field by identifying research gaps, application possibilities, and extending the traditional insurance-specific value chain within Insurtech as a separate component. This theoretical extension shows an ongoing insurance industry transition from standardization and product to the platform-based business model and ServiceDominant Architecture (SDA), and relies on recent studies on Insurtech and their influence made by Zolnowski and Warg (2017), Stoeckli, Dremel and Uebernickel (2018), and Warg et al. (2019). Scientific studies of digital insurance in East Europe and Baltic countries also reveal that the rise of digitization, digitalization processes, and digital transformation strategies is only determined by global insurance business tendencies, technological development and costcutting, and correlates to external factors as regional economic growth and the index of internetization (Klapkiv et al., 2018; Łyskawa et al., 2019; Zarina et al., 2019 


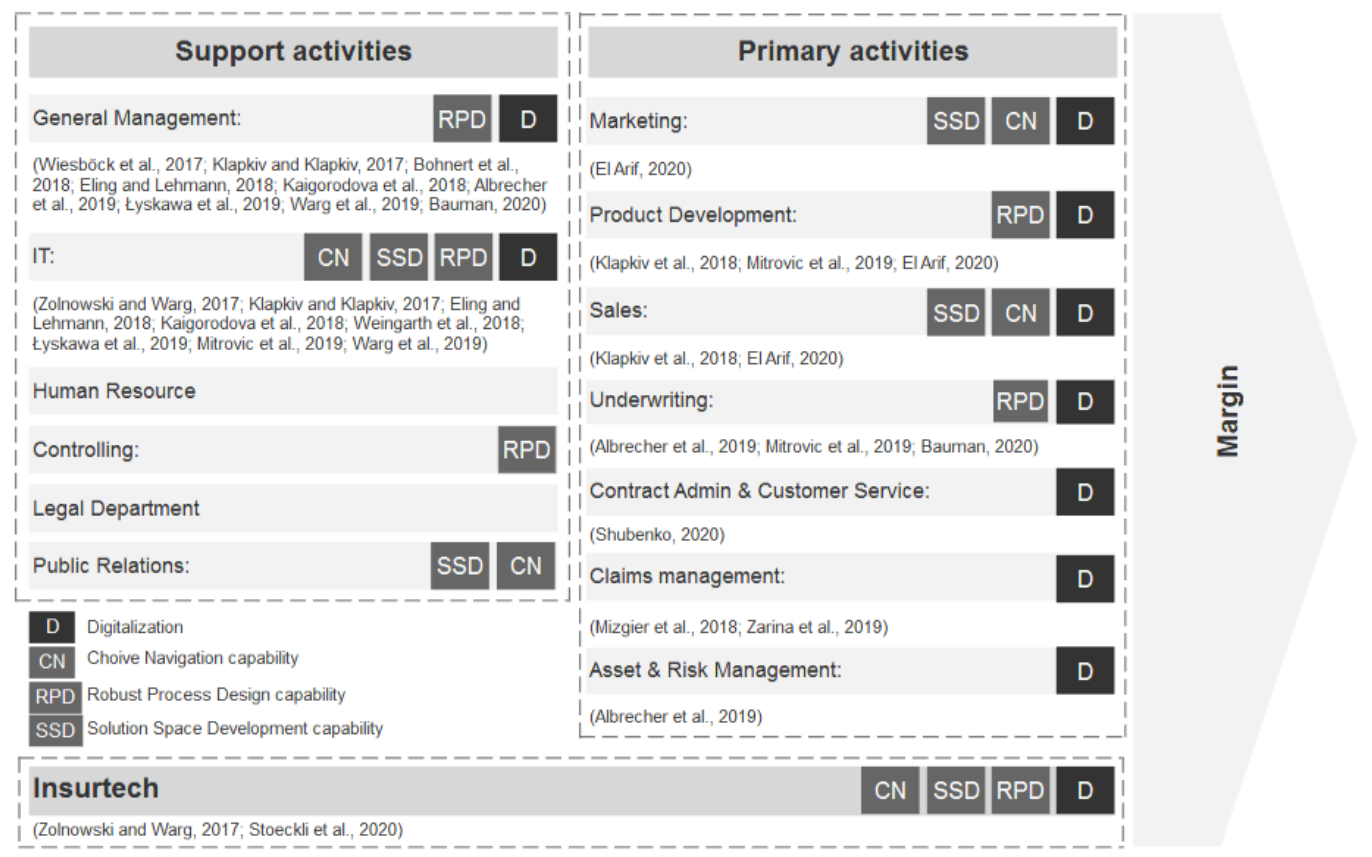

Figure 1. Digitalization and Mass Customization capabilities widespread in the insurance-specific value chain

Source: created by authors by following Porter, 1985; Salvador, Holan and Piller, 2009, Eling and Lehmann, 2018

As per Figure 1, the outcomes of the Mass Customization concept with personalization features can be identified in digital insurance marketing, product development or underwriting activities. Application of the modern e-Mass Customization concept and online customization frameworks allows the insurance industry firms to minimize the influence of the traditional Mass Customization concept version obstacles, including optimization of external demand variety versus internal product/process complexity and shortening the implementation period (Kamis, Stern \& Ladik, 2008; Daaboul, Bernard \& Laroche, 2012). The impact and the role of digitalization are specified in Table 1.

As per Table 1, the major influence and the role of digitalization stands in the Solution Space Development stage, where it is recognized internally in organization distribution platforms and by external assistance to end-users. Outcomes of the digitalization in the stage of
Robust Process Design are mostly visible internally, on a process management side, while the most visible influence on external end-users is in the Choice Navigation stage. In the insurance practice, this digital business-to-customer business model based on Mass Customization capabilities is best recognized by flexible, wellintegrated frontend and backend structures, selfservice-based sales platform for end-users. Besides, the online insurance platforms provide a proper amount of information, additional services, customization options and convenient access to personalized information for different types of end-users. Overall, these new synergy forms of digitalization and Mass Customization domains in the insurance service and platforms indicate not only a recent discourse of theoretical studies but also reveal key practical outcomes of digital insurance transformation implications. 
Table 1. Role and impact of digitalization on Mass Customization capabilities

\begin{tabular}{|l|l|}
\hline \multicolumn{1}{|c|}{ Capability } & \multicolumn{1}{c|}{ Digitalization role and impact } \\
\hline $\begin{array}{l}\text { Solution Space } \\
\text { Development } \\
\text { (SSD) }\end{array}$ & $\begin{array}{l}\text { To the organization and end-users: digitalization reflects as an intermediary } \\
\text { technological toolkit used to identify and translate a large scale of preferences of } \\
\text { diverge end-users at an early stage design into unique goods or a service version } \\
\text { at later stages as well as to provide possibilities to make virtual testing of it in } \\
\text { pre-stage. }\end{array}$ \\
\hline $\begin{array}{l}\text { Robust } \\
\text { Process }\end{array}$ & $\begin{array}{l}\text { To the organization: process automation elements, features of the process, and } \\
\text { system agility and flexibility are taken from the digitalization domain and widely } \\
\text { applied in the reuse or recombination of existing organizational resources for } \\
\text { higher process modularity and better supply chain management. }\end{array}$ \\
\hline $\begin{array}{l}\text { Choice } \\
\text { Navigation } \\
\text { (CN) }\end{array}$ & $\begin{array}{l}\text { To the end-users: application of results from the Big Data and Big Data analytics } \\
\text { to a personalized communication field or web-based automatic recommender } \\
\text { systems minimizes the risk of mass confusion and assists in decision making to } \\
\text { the UI of an end-user as well as encourages more active user participation in co- } \\
\text { creation and co-design processes. }\end{array}$ \\
\hline
\end{tabular}

Source: created by the authors based on Kamis et al., 2008; Salvador et al., 2009; Piller, Thorsten, Ihl and Salvador, 2014; Risdiyono, Imam and Affan, 2016

\section{Digital Insurance Transformation Implications and Practical Outcomes}

Digitalization determines primary and supporting activities in the insurance-specific value chain at the operational infrastructure and strategical decision level. A strong impact on the meaning of the insurer structure of all insurance ecosystems is noticed (Eling \& Lehmann, 2018; Albrecher et al., 2019; Łyskawa et al., 2019). Recently, the adoption of agile approaches to manage existing IT infrastructure and overall organization limitations for in-house development has been spotted (Bohnert et al., 2019). Due to the COVID-19 situation, traditional insurers are expected to remove a continuous internal tension among IT operations, development processes, and financing procedures-functions. Building new, fully digital customizable products and personalized service platforms with the help of digital service providers and new intermediaries in the insurance market has become a reality and goal (Stoeckli et al., 2018). General trends and outcomes of insurance digitalization are discussed in Table 2.

Comparing Table 2 to Figure 1, presents a new angle to consider: showing that digitalization has a positive effect on the structural and conceptual levels of the insurance industry. Otherwise, these digital enablers of insurance modernization still struggle to overcome the nature and dominant features of traditional insurance processes and products. Traditionally, insurance products are designed or moderated after a detailed analysis of market interest and profitability by using classification or regression methods based on classical actuarial methods (Albrecher et al., 2019). The traditional insurance business model and value chain can be defined as a combination of management on stochastic claims, diversification of unsystematic risks, and inverse production cycle application in the insurance service (Wiesböck et al., 2017; Klapkiv et al., 2018). These components are built around insurance customer needs, full assets protection, reasonable, comparable, transparent pricing and timeless claims management (Zolnowski \& Warg, 2017).

Currently, the insurance industry benefits from digitalization by supporting the driving needs of end-users, which are stable and easy to follow, but behavior models are dynamic and influenced by a highly personalized experience from tangible product markets such as FMCG (Fast Moving Consumer Goods) and the intangible products and services of the banking industry. 
Table 2. Key advantages and disadvantages of digitalization in the insurance industry

\begin{tabular}{|l|l|}
\hline \multicolumn{1}{|c|}{ Advantages } & \multicolumn{1}{|c|}{ Disadvantages } \\
\hline $\begin{array}{l}\text { Organizational and industry structure changes: } \\
\text { new, digital transformation dedicated } \\
\text { positions/unis, digital intermediaries. }\end{array}$ & $\begin{array}{l}\text { Weak digital leadership model and e-reputation } \\
\text { of insurance companies. }\end{array}$ \\
\hline $\begin{array}{l}\text { Transition from the transaction and } \\
\text { standardization insurance concept to the } \\
\text { combined online customization and } \\
\text { personalization-based insurance concept. }\end{array}$ & $\begin{array}{l}\text { Process and separate persona product lines } \\
\text { focused on digitalization only partly. }\end{array}$ \\
\hline $\begin{array}{l}\text { The shift from the distribution and supply- } \\
\text { driven product design to the consumer and } \\
\text { demand-driven product design. }\end{array}$ & $\begin{array}{l}\text { Low compatibility between the traditional } \\
\text { multichannel distribution strategy, IT } \\
\text { infrastructure, and the new personalized, } \\
\text { omnichannel marketing, sales strategy, and } \\
\text { digital service platforms. }\end{array}$ \\
\hline $\begin{array}{l}\text { Introducing modern omnichannel and multi- } \\
\text { access solutions-based sales and service } \\
\text { platforms. }\end{array}$ & $\begin{array}{l}\text { Low technical capabilities to access, exploit, and } \\
\text { apply sales and risk-related big data on a large } \\
\text { scale. }\end{array}$ \\
\hline $\begin{array}{l}\text { Improving operational efficiency and cost level } \\
\text { in sales, claim management, and back-office } \\
\text { operations. }\end{array}$ & $\begin{array}{l}\text { The legal environment with strict and intense } \\
\text { regulation on end-user's data and rights } \\
\text { protection in digital platforms. }\end{array}$ \\
\hline
\end{tabular}

Source: created by authors by following Wiesböck et al., 2017; Stoeckli et al., 2018; Albrecher et al., 2019; Bohnert et al., 2019; Zarina et al., 2019; El Arif, 2020

The new combined approach to the needs of the insurance service end-users is reflected in multiple transformations of organizations and industries, new digital platforms, and the popularity of a multi-access omnichannel strategy. Practical examples of organizational restructuration are recent appointments in the new positions of Chief Digital Officer, Digital Product Owner or Head of Transformation, and the establishment of dedicated digital transformation units (Wiesböck et al., 2017). From the perspective of product underwriting and sales, the advantages of digital technologies and the application of online sales platforms are best recognized in simple, private lines products like Motor Third Party Liability (MTPL) or travel insurance (Klapkiv et al., 2018). Complex non-life insurance products such as property and CASCO insurance gain popularity from digital end-users and service providers at slower pace. Fast technological advancements made health insurance the most digitalization-affected line of the insurance business (Mitrovic, Trifunovic \& Ranđelović, 2019; Zarina et al., 2019). Otherwise, several key obstacles slow down the progress and need to be overcome for a full scope implication of digital insurance transformation:

- A fragmented, limited, and non-holistic approach to digital transformation strategies;

- Technical resources and knowledge limitations to develop a unified digital distribution and service platform for direct sales and distribution partners, and access to external digital data sources, proper management on a new pricing, risk, and marketing-related big data (Wiesböck et al., 2017; El Arif, 2020).

Moreover, all current insurance firms should consider digitalization within traditional business logic and technology compatibility issues and evaluate the influence of new laws, business ethics and a change of corporate mindset (Albrecher et al., 2019). Insurers struggle with alignment to legal compliance procedures or requirements of personal data privacy and availability and also fight to solve new issues of information asymmetry. It is essential to reduce the digital information 
asymmetry between a client and an insurer under reasonable conditions of rising costs and risk management (Klapkiv \& Klapkiv, 2017; Albrecher et al., 2019; Łyskawa et al., 2019). Potential risks after the information asymmetry in digital insurance products sales and after-sale services cover insufficient access to information or understanding of the product, service, or its provider, and data security, as it can lead to potential misuse of personal data or exclusion of consumer segments due to a granular risk categorization. End-users can suffer due to minimal real contact and be mistaken by information from multiple online data sources, as the content may be illegitimate or misleading to decide unbiased (IAIS, 2018).

The global COVID-19 situation has fostered changes in insurance industry operational models and structure, which are recognized not only internally, but also by an extensive entry of new digital intermediaries and service providers. New firms aim to combine and lead all four key intermediary roles of information aggregation, facilitation of processes, matching and building trust in branding (Stoeckli et al., 2018). If traditional insurers aim to keep profit margins and increase operational efficiency, agile and combined solutions of traditional insurance management and innovative technologies should be applied in a short period.

\section{RESEARCH METHODOLOGY}

Research supports previous scientific analyses on the Baltic non-life insurance market focusing on digitalization, online customization trends, identifying the practical level of as-is digital solutions, and Mass Customization capabilities in online insurance platforms. Existing non-life insurance online platforms and insurance experts acting across Baltic countries were selected as a research object. The research follows a triangulation logic of a combination of an online expert survey with a simplified Fuzzy and Likert scale-based questionnaire and analysis techniques of embedded, descriptive, and comparative types of case studies. Selection of online surveys with a structured questionnaire format was carried out due to the application of the rating scales method to counter experts time consumption and semantical bias, identified in the unstructured questionnaire. The selection follows an overall admission to be a valuable tool and source of qualitative information and a complement to the information extracted by using quantitative techniques and data sources (Quir'os, Alonso \& Pancho, 2016). The detailed survey questionnaire is presented in Table 3.

Table 3. Questionnaire of online expert survey

\begin{tabular}{|c|c|c|}
\hline Structure & Content & Distribution \\
\hline $\begin{array}{l}15 \text { Closed-ended questions and } \\
\text { statements: }\end{array}$ & $\begin{array}{l}\text { Combination of full-blown Likert } \\
\text { scale and Fuzzy method of } 10\end{array}$ & $\begin{array}{l}\text { 1) Created via Typeform } \\
\text { platform }\end{array}$ \\
\hline 1) 3 Demographic questions & points in scale: & \multirow{4}{*}{$\begin{array}{l}\text { 2) Distributed by directly } \\
\text { approaching via } \\
\text { personal/working email } \\
\text { and Linkedin messaging }\end{array}$} \\
\hline $\begin{array}{l}\text { 2) } 3 \text { Digitalization related } \\
\text { questions }\end{array}$ & $\begin{array}{l}\text { 1) A full-blown Likert scale } \\
\text { applied in } 9 \text { questions }\end{array}$ & \\
\hline $\begin{array}{l}\text { 3) } 3 \text { Mass Customization } \\
\text { capabilities questions }\end{array}$ & $\begin{array}{l}\text { 2) Simplified Fuzzy logic used } \\
\text { in a series of } 3 \text { statements }\end{array}$ & \\
\hline $\begin{array}{l}\text { 4) } 6 \text { Online insurance } \\
\text { platforms questions and } \\
\text { statements }\end{array}$ & $\begin{array}{l}\text { 3) } 10 \text { point scale }(0 \text { - very } \\
\text { poor, } 5 \text { - Neutral, } 10 \text { - } \\
\text { Excellent) }\end{array}$ & \\
\hline
\end{tabular}

Source: created by the authors

The questionnaire has 15 closed-ended questions or statements to evaluate: 12 relate to the research topic and aim, 3 relate to working experience, working field, and country of respondents. Questions were formulated by a full-blown Likert scale and a Fuzzy method of 10 
points in the scale. A simplified and combined logic of Fuzzy Logic Techniques (FTL) applied to the Likert scale questionnaire provides the following advantages:

- Reduces a possibility of imprecision, uncertainty, and subjective question interpretation as offers a varying height of related fuzzy sets (Gómez, Gómez \& Gans, 2012, p. 23; Quir'os, Alonso \& Pancho, 2016, p. 451);

- Provides well-aligned answers to the use in statistical computing techniques via
MaxQData or RStudio programs, descriptive and comparative analyses (Quir'os et al., 2016, p. 452);

- Reduces the weakness of the conventional Likert scale as inflexibility, measures latent variables, estimates varying data interval ranges (Rattanalertnusorn, Thongteeraparp \& Bodhisuwan, 2013; Vonglao, 2017, pp. 337-338).

The values of the rating scales are presented in Table 4.

Table 4. Values of judgment scale

\begin{tabular}{|l|l|l|}
\hline $\begin{array}{c}\text { The } \\
\text { quantitative } \\
\text { rate in scale }\end{array}$ & $\begin{array}{c}\text { The qualitative } \\
\text { equivalent of the } \\
\text { rate }\end{array}$ & Additional information \\
\hline 1 & Very low & Evaluation object is favored the lowest by experts \\
\hline 2 & Low & \\
\hline 3 & Weak & \\
\hline 4 & Rather weak & Evaluation object has a neutral evaluation by experts \\
\hline 5 & Neutral & \\
\hline 6 & Satisfied & \\
\hline 7 & Rather good & \\
\hline 8 & Good & \\
\hline 9 & Very good & Evaluation object is favored the highest by experts \\
\hline 10 & Excellent & \\
\hline
\end{tabular}

Source: created by the authors by following Saaty, 2008; Goepel, 2019.

The selection of modified judgment scales with integers from 1 to 10 and their qualitative equivalent was made as traditional Saaty 9 point and other fundamentals AHP (the analytic hierarchy process) scales for pairwise comparisons have local weights that are unequally dispersed (Goepel, 2019, p. 3). The 10point range scale is the most common practice, and Saaty and Ozdemir recommend keeping the maximum criteria of the magic numbers +7 or -2 (Goepel, 2019, p. 4).

The questionnaire was created and the survey was conducted in English via the Typeform platform. Survey invitations were sent by email and private messages on the Linkedin platform. The survey lasted from 12 July to 17 August and consisted of 3 main steps, provided in Figure 2.
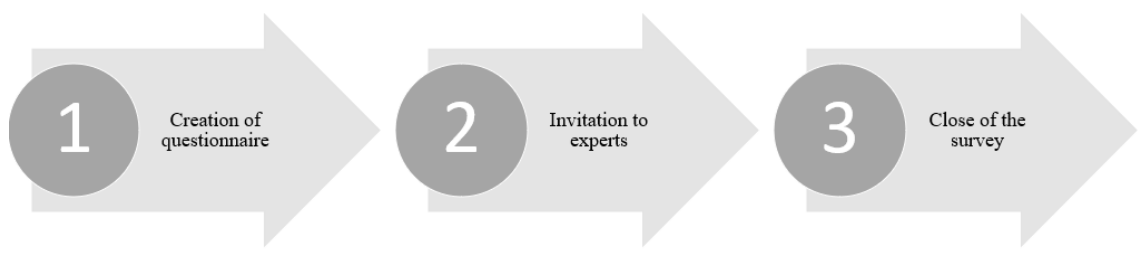

Figure 2. Expert survey process steps and logic Source: created by the authors 
The sample of this research is defined as being formulated under the non-probability sampling logic and the judgmental-purposive sampling method. A selection of the sampling logic and methods was influenced by the purpose of the study and the knowledge and judgment of researchers towards the target audience (Etikan \& Bala, 2017). This logic and methods fit under a small scope of the survey and profile of respondents, presenting individuals with a specific set of qualitative indicators as professional skills, working experience, and knowledge in the financing field. The sample size of experts followed requirements to have at least +1 experts to compare to the total number of evaluation indicators: Digitalization, Standardization, Personalization, Customization, Capability of Choice Navigation, Capability of Robust Process Design, and Capability of Solution Space Development. Increasing the expert number reduces the possibility of anomalies or subjectivity in results. In the case of an equalweighted composite judge, the actual empirical validities are obtained by aggregating evaluations of 3 and 7 judges with an accuracy of $>90 \%$. When the number of experts increases, so does this indicator slowly increase until it reaches $100 \%$, next to $17-18$ expert judges (Libby \& Blashfield, 1978; Baležentis \& Žalimaitè, 2011, p. 25).

The research population involves experts meeting the following criteria:

1.> 5 years of working experience in the nonlife insurance field;

2.Working in the field of the Insurance or Banking industries and digital applications or platforms. Experts from areas such as Sales, Marketing, IT (Project Management) and Product and process development/underwriting were selected, as this research topic relates to primary insurance value chain activities from operational, product, and technological maturity points of view;

3. Being in the workplace of an organization in the Insurance or Banking industries physically located in the Baltic region (Lithuania, Latvia, or Estonia).

Each expert was depersonalized and given a numerical identification by the author. A more detailed presentation of anonymized experts is provided in Table 5.

Table 5. Presentation of experts' profile

\begin{tabular}{|l|l|l|l|}
\hline $\begin{array}{c}\text { Expert } \\
\text { code }\end{array}$ & Country & $\begin{array}{c}\text { Working experience in the } \\
\text { finance sector }\end{array}$ & \multicolumn{1}{|c|}{ Working field } \\
\hline IE 1 & Estonia & $11-16$ years & Marketing \\
\hline IE 2 & Estonia & $5-10$ years & IT (including IT project management) \\
\hline IE 3 & Estonia & $11-16$ years & $\begin{array}{l}\text { Product and process } \\
\text { development/underwriting }\end{array}$ \\
\hline IE 4 & Latvia & $11-16$ years & Sales \\
\hline IE 5 & Latvia & $11-16$ years & Sales \\
\hline IE 6 & Latvia & $5-10$ years & Sales \\
\hline IE 7 & Latvia & $11-16$ years & Sales \& Marketing \\
\hline IE 8 & Lithuania & $5-10$ years & $\begin{array}{l}\text { Sales \& Marketing, IT } \\
\text { (Including IT project management) }\end{array}$ \\
\hline IE 9 & Lithuania & $16+$ years & Sales \\
\hline IE 10 & Lithuania & $11-16$ years & IT (including IT project management) \\
\hline IE 11 & Lithuania & $11-16$ years & $\begin{array}{l}\text { Product and process } \\
\text { development/underwriting }\end{array}$ \\
\hline
\end{tabular}

Source: created by the authors

Eleven experts were invited to the online survey: 4 from Lithuania and Latvia, 3 from Estonia. An important reliability indicator is working experience. Most respondents, $73 \%$, have $>11$-year experience, $27 \%$ have $5-10$-years of experience in the financial sector. Another 
reliability indicator is a great variety of professional occupancy. Most experts, 6, were from Sales areas: Sales, Sales \& Marketing, and Marketing. One expert was from mixed positions covering several working fields, 2 experts selected IT (including IT project management), and 2 selected Product and process development/underwriting. The selection of experts working fields is related to the research object and relies on the conceptual framework in Figure 1, where widespread use and influence of digitalization and three Mass Customization capabilities were identified in primary activities of the insurance-specific value chain.

\section{RESEARCH RESULTS AND ANALYSIS}

\section{Procedure and Methodology of Research} Results Analysis

Results are presented according to the analysis and systemization of answers in specific questionnaire questions or statements and are covered in a descriptive type of embedded case study relying on the hypothesis and theoretical analysis. Conclusive confirmations or rejections of the hypothesis are formulated. Analysis and systemization of questionnaire answers carried under the methods of experts' opinions ranging and Kendall's Coefficient of Concordance (W), as calculated by the following formula:

$$
W=\frac{8 \mathrm{~S}}{\mathrm{r}^{2} m\left(m^{2}-1\right)}
$$

Figure 3. The formula of Kendall's Coefficient of Concordance (W)

Source: created by the authors by following Podvezko, 2005, p. 102; Podvezko and Sivilevičius, 2013, p. 397

Table 6. Ranking of experts' evaluation

\begin{tabular}{|c|c|c|c|c|c|c|c|c|c|c|c|}
\hline & \multirow{2}{*}{$\begin{array}{c}\begin{array}{c}\text { Ranked } \\
\text { object*: }\end{array} \\
\text { Question: }\end{array}$} & \multicolumn{3}{|c|}{1} & \multirow{2}{*}{$\begin{array}{l}2 \\
6\end{array}$} & \multirow{2}{*}{$\begin{array}{l}3 \\
7\end{array}$} & \multirow{2}{*}{$\begin{array}{l}4 \\
8\end{array}$} & \multirow{2}{*}{$\begin{array}{l}5 \\
9\end{array}$} & \multirow{2}{*}{$\begin{array}{c}6 \\
10\end{array}$} & \multirow{2}{*}{$\begin{array}{c}7 \\
11\end{array}$} & \multirow{2}{*}{$\begin{array}{c}\text { Total } \\
\text { rank } \\
\text { per } \\
\text { expert }\end{array}$} \\
\hline & & 3 & 4 & 5 & & & & & & & \\
\hline \multirow{11}{*}{$\begin{array}{l}\text { Expert } \\
\& \\
\text { Rank }\end{array}$} & IE 1 & 2 & 2 & 2 & 2 & 2 & 2 & 2 & 2 & 2 & 18 \\
\hline & IE 2 & 6 & 6 & 7 & 6 & 7 & 8 & 4 & 4 & 5 & 53 \\
\hline & IE 3 & 5 & 6 & 5 & 7 & 7 & 7 & 3 & 5 & 7 & 52 \\
\hline & IE 4 & 6 & 7 & 9 & 9 & 10 & 10 & 9 & 3 & 1 & 64 \\
\hline & IE 5 & 2 & 2 & 2 & 2 & 2 & 2 & 2 & 2 & 2 & 18 \\
\hline & IE 6 & 9 & 9 & 8 & 8 & 6 & 6 & 7 & 6 & 7 & 66 \\
\hline & IE 7 & 6 & 6 & 8 & 6 & 5 & 6 & 3 & 5 & 4 & 49 \\
\hline & IE 9 & 2 & 2 & 2 & 2 & 2 & 2 & 2 & 2 & 2 & 18 \\
\hline & IE 10 & 6 & 4 & 8 & 7 & 7 & 6 & 4 & 4 & 4 & 50 \\
\hline & IE 14 & 7 & 7 & 9 & 7 & 7 & 7 & 3 & 5 & 4 & 56 \\
\hline & IE 16 & 7 & 8 & 9 & 8 & 6 & 8 & 5 & 6 & 4 & 61 \\
\hline \multicolumn{2}{|c|}{$\begin{array}{l}\text { Total rank per } \\
\text { question: }\end{array}$} & 58 & 59 & 69 & 64 & 61 & 64 & 44 & 44 & 42 & \\
\hline
\end{tabular}

Source: created by the authors by following Podvezko, 2005; Podvezko and Sivilevičius, 2013

${ }^{*}$ Rank object here stands for evaluation criteria with the following values: 1 - Digitalization; 2 Standardization; 3 - Personalization; 4 - Customization; 5 - Capability of Choice Navigation; 6 Capability of Robust Process Design; 7 - Capability of Solution Space Development 
The method of ranging experts' opinions was applied and presented in Table 6.

The following are indicators and their values used in the formulas:

- $S$ is the sum of squares of deviations of each ranked object;

- $m$ is the number of objects being ranked, in this case, equal to 7;

- $r$ is the number of raters, in this case, equal to 8. After ranking results of experts' opinions, the results of three experts (IE1, IE5, and IE9) were eliminated due to limited objectivity and simulation in the survey, as provided in Table 6.

The following steps are taken to calculate Kendall's Coefficient of Concordance:

1.Calculation of a total rank-sum $\mathrm{Ci}$ using the formula in Figure 4. The indicator had a value of 451 .

$$
\sum_{i=1}^{m} c_{i}=\frac{1}{2} r m(m+1)
$$

Figure 4. The formula of indicator $C_{i}$

Source: created by the authors by following Podvezko, 2005, p. 102; Podvezko and Sivilevičius, 2013, p. 397

The character $r$ is the number of experts, the character $m$ is the number of ranked objects.

2.Calculation of a general average of ranks using the formula in Figure 5. The indicator had a value of 64 .

$$
\overline{\mathrm{c}}=\frac{1}{2} r(m+1)
$$

Figure 5. The formula of indicator $\bar{c}$

Source: created by the authors by following Podvezko, 2005, p. 102; Podvezko and Sivilevičius, 2013, p. 397

The character $r$ is the number of experts; the character $m$ is the number of ranked objects.

3.Calculation of the sum of the squares of deviations from the sum of rank for the values of each criterion from the total mean value. The indicator S had a value of 763; the calculation was made using the formula in Figure 6.

$$
S=\sum_{i=1}^{m}\left(c_{i}-\bar{c}\right)^{2}
$$

Figure 6. The formula of indicator $\mathrm{S}$

Source: created by the authors by following Podvezko, 2005, p. 102; Podvezko and Sivilevičius, 2013, p. 397

4. Calculation of the maximum value of the sum of the squares of deviations $S_{\max }$. The indicator had a value of 149,769 ; the calculation was made using the formula in Figure 7.

$$
S_{\text {max }}=\sum_{i=1}^{m}\left(r \times i-\frac{1}{2} r(m+1)\right)^{2}=\frac{r^{2} m\left(m^{2}-1\right)}{8}
$$

Figure 7. The formula of indicator $S_{\max }$

Source: created by the authors by following Podvezko, 2005, p. 102; Podvezko and Sivilevičius, 2013

Kendall's Coefficient of Concordance (W) was calculated using the formula in Figure 3. The concordance coefficient $\mathrm{W}$ has a value of 0.28 , which illustrates a low agreement and concordance among experts towards ranked objects (Podvezko, 2005; Podvezko \& Sivilevičius, 2013). The indicator of the Chisquare distribution $\left(\mathrm{X}^{2}\right)$ was calculated in order to evaluate the significance of the concordance coefficient and the consistency of the group of raters. The indicator $X^{2}$ has a value of 13.44 . The value of the Chi-square distribution $\left(\mathrm{X}^{2}\right)$ indicator was compared to the value of the critical Chisquare distribution () by following a value from the chi-square distribution table, using a degree of freedom $\mathrm{v}=\mathrm{m}-1=6$ and significance level $\alpha=0.05$. The value of the critical Chi-square distribution () is equal to 12.59 and indicates that the opinions of experts are consistent (Podvezko, 2005; Podvezko \& Sivilevičius, 2013).

\section{Research Results}

A positive but twofold as-is status within the digitalization in the Baltic non-life insurance online platforms was identified from expert answers to questions 3, 4, and 5. Key insights are:

1.The overall digitalization level is between Satisfied and Rather Good; the average judgment of experts is 6.5 points;

2.The preparation level for digital solutions from a service provider side is between Satisfied and Rather Good; the average judgment of experts is 6.6 points; 
3. Digitalization is behind the actual needs of end-users and is defined between the levels Rather Good and Good; The average judgment of experts is 7.9 points.

Comparing answers on a country level, the highest average evaluation of digitalization in insurance is in Latvia ( 7 points), a similar average evaluation is in Lithuania (6.7 points), and the lowest average evaluation is in Estonia (5.5 points). An assumption is that the insurance service, products, and the financial sector in Estonia are at a higher maturity level than Latvia and Lithuania. End-users from Estonia also have been familiar with digital solutions for a longer time.

Identification of the predominant as-is feature in Baltic non-life insurance online platforms was made after the analysis of customization, personalization, and standardization features in questions 6, 7 and 8. Key insights are:

1.The standardization level is slightly over Satisfied. The average judgment of experts is 7.25 points. Comparing answers on a country level, standardization is mostly expressed in Latvia (average of 7.7 points), similarly in Lithuania (average of 7.3 points), but experts from Estonia defined it between levels Satisfied and Rather Good (average of 6.5 points).

2.The personalization level is between Satisfied and Rather Good. The average judgment of experts is 6.85 points. Experts from Latvia and Estonia defined personalization as Rather Good (average of 7.0 points), experts from Lithuania evaluated it as near to Rather Good (average of 6.7 points).

3.The customization level is slightly over level Satisfied. The average judgment of experts is 7.25 points. Comparing answers on a country level, customization is mostly expressed in Estonia (average of 7.5 points), similarly in Latvia (average of 7,3 points), but experts from Lithuania defined it as the average of 7.0 points.

Additional analysis was carried by applying a simplified Fuzzy AHP research logic. Experts were asked to select one preferable statement out of three pairs in questions 13,14, and 15. Selected pre-dominant features in existing nonlife online insurance platforms from the evaluations are summarized in Figure 8.

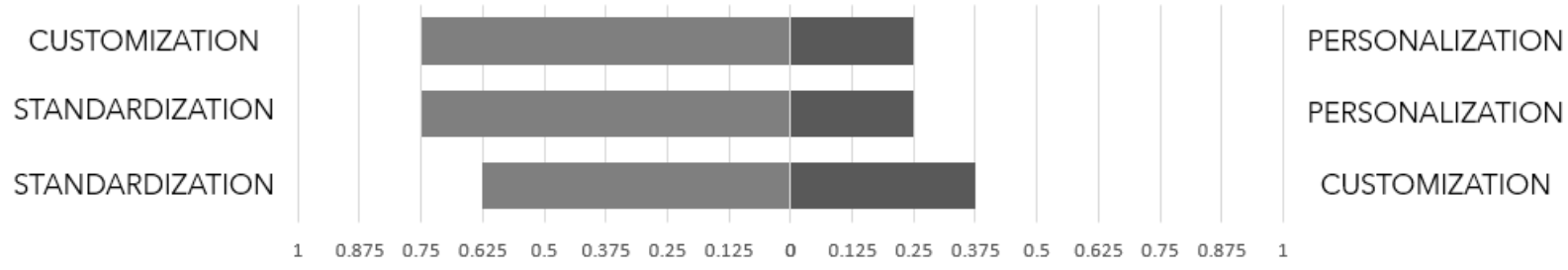

Figure 8. Baltic experts evaluation on pre-dominant features in existing non-life online insurance platforms

Source: created by the authors

Results of expert judgments have a twofold meaning. The summarized evaluation confirms the dominant features of customization over features of personalization and a significant dominance of standardization features over personalization and customization features. The remarkable differences were identified comparing answers on a country level, where all three Baltic countries have different preferences in the customization and personalization pair: both experts from Estonia selected customization as a fully dominant feature; 2 of 3 experts from Latvia agreed on customization dominance; but experts from Lithuania judged in the opposite - 2 of 3 chose personalization. Comparing pairs of standardization versus personalization and customization versus standardization, a unified pattern is identified: the judgment of Estonian experts split equally within both comparison pairs; experts from Lithuania were unified in both comparison pairs by fully supporting a dominance of 
standardization, while experts from Latvia partly (2 of 3) support a dominance of standardization. These heterogeneous judgment results on a country level support open discussions about digital transformation in the Baltic insurance industry, where one of the key driving components is increasing penetration of combined digitalization and customization solutions in insurance platforms.

Investigation of the spread of three main capabilities for successful Mass Customization implementation was made in questions 10,11 , and 12. Summarized evaluations of expert answers are provided in Table 7.

Table 7. Experts evaluation on Mass Customization capabilities Baltics non-life insurance online platforms

\begin{tabular}{|l|l|l|l|l|}
\hline \multirow{2}{*}{ Capability } & \multicolumn{4}{c|}{ The average evaluation: } \\
\cline { 2 - 5 } & \multicolumn{1}{|c|}{ in Baltics } & \multicolumn{1}{c|}{ in Lithuania } & \multicolumn{1}{c|}{ in Latvia } & \multicolumn{1}{c|}{ in Estonia } \\
\hline Choice Navigation & 4,75 points & 4,8 points & 6,3 points & 3,5 points \\
\hline Robust Process Design & 4,75 points & 5 points & 4,7 points & 4,5 points \\
\hline $\begin{array}{l}\text { Solution Space } \\
\text { Development }\end{array}$ & 4,5 points & 4 points & 4 points & 6 points \\
\hline
\end{tabular}

Source: created by the authors

Evaluation of all three capabilities is between levels Rather Weak and Neutral, but major differences were identified on the country level:

1.The capability of Choice Navigation has the highest evaluation in Latvia: it is between the levels Satisfied and Rather Good. The level in Estonia is Weak-Rather Weak and in Lithuania it is Rather Weak-Neutral.

2.The capability of Robust Process Design has a similar evaluation in all Baltic countries and received the highest evaluation (average of 5.0 points) in Lithuania. A low difference in evaluations can be grounded by this main orientation to the re-use of existing organizational and value-chain resources to deliver digitalized solutions and is weakly expressed and visualized in the final solution.

3.The capability of Solution Space Development has the highest evaluation in Estonia, where it is Satisfied, while in Latvia and Lithuania it is at the level Weak.

Opposite judgments of Choice Navigation and Solution Space Development capabilities in Latvia and Estonia illustrate different maturity and overall spread levels of Mass Customization in digital platforms. The primary focus of insurance organizations in Latvia is to create a simple, effective, and user-friendly product configuration and recommendation system via digital solutions, while in Estonia the strongest part is an organizational capability to understand their customer needs of products and services.

\section{LIMITATIONS, FUTURE DIRECTIONS, AND DISCUSSION}

The conducted research and results analysis have several limitations. Together with the simplified Fuzzy AHP research logic, the application of the multi-value Qualitative Comparative Analysis (mvQCA) methodology and tools are required to prove the results of the survey. The R tool and a Qualitative Comparative Analysis (QCA) package with functions as crisp sets (csQCA), temporal (tQCA), multi-value ( $m v Q C A$ ), and fuzzy sets (fsQCA) can be used. The selection of the QCA methodology allows a connection of qualitative and quantitative data imperatives in descriptive case studies. Using the Boolean algorithm in the $\mathrm{R}$ tool results in $\mathrm{a}$ minimal causal combination that explains and verifies a given hypothesis of the research phenomenon in a detailed and accurate way. Another limitation of the conducted research is a focus on insurance products of a private customer, their online distribution platforms, and traditional insurance firms while insurance products of corporate customers, their 
distribution and digitalization as well as new digital intermediaries - Insurtech - were not analyzed. These sub-topics have the significant practical potential for innovation, digitalization, and customization and are to be considered as a potential for future research directions.

Further studies should also focus on a detailed investigation of new, combined online customization frameworks for non-life insurance online platforms, which should be created under end-user needs for widely expressed customization options, tailored products, and personalized assistance. Additional analysis on end-user behavior and attitude to co-creation in new digital and customized insurance platforms at country and Baltic region levels are needed. Complementary aspects as traditional determinants of the insurance purchase decision and Berliner's insurability criteria should be investigated under digital non-life insurance online platforms and the e-Mass Customization concept.

The conducted research revealed points for an open discussion. First, overall evaluations of the Baltic insurance industry within digitalization status confirm statements of past researchers Zolnowski and Warg (2017), Stoeckli et al. (2018), and Warg et al. (2019) - about the ongoing transition to the online platform-based business model and Service-Dominant Architecture (SDA). Here a key question for a discussion is how much this digital transformation in the Baltics is still internally oriented and technical-driven or has innovative customer-centered solutions based on a combination of disruptive technologies, personalized service level and advanced product customization. The low evaluation of personalization level and features in all analyzed countries and a significant dominance of standardization features over personalization and customization features allows formulating assumptions that the Baltic market incumbents deal with the same challenges as Zolnowski and Warg (2017) identified in the case of incumbents of the German insurance market. These challenges are fostering modernization of legacy system infrastructure and adoption of service mindset and operation of existing data and knowledge of the customer in digital format. Besides, low evaluations between the levels
Rather Weak and Neutral of all three Mass Customization capabilities in the Baltic online platforms confirm assumptions of Wiesböck et al., 2017, which state that insurers struggle to develop a unified omni-channel distribution system.

\section{CONCLUSIONS}

This study's main scientific contributions rely on summarized theoretical assumptions and an extension of preceding case studies of the Digitalization and Customization research domains in the Baltic non-life insurance market. A high practical and theoretical interest in digital service solutions and digitalization is mostly noticed at primary activities and the strategic management level of insurance companies but is insufficiently aligned in practice and operational support. For a long time, insurance field researchers and practitioners considered digitalization in a narrow, technological approach. Only in the past decade has a transition to a holistic and combined technological-management approach been noticed.

The practical analysis of digitalization and Mass Customization capabilities in the Baltic non-life insurance online platforms also contributed to the main findings. The consensus of the experts' evaluation identified the case of service providers' preparation for digital solutions as the weakest part. A demand level of an end-user for digital solutions in all three countries is leading. The overall digitalization evaluation indicates a need to improve insurance organization preparation for digital distribution solutions by investing more in customizable insurance product options and personalized service availability.

The expert-based judgment on standardization, like the predominant as-is feature in existing online insurance platforms, has a twofold meaning. An assumption is that the predominant online insurance product base and user experience in the online sales platforms are built around a strictly legally regulated and standardized Motor Third Party Liability (MTPL) product with low customization and personalization options. This evaluation also illustrates that Baltic insurance organizations are still in transition from the Mass Production 
approach and deal with multiple internal questions as resource reallocation/re-usage, ensuring a balance between creating unlimited product variability options and keeping overall operational efficiency profitable numbers.

The investigation of three key capabilities of Mass Customization resulted in evaluations within the levels Rather Weak and Neutral. It revealed the heterogeneous background and key differences among Lithuanian, Latvian, and Estonian non-life insurance online platforms. The opposite evaluation of Choice Navigation and Solution Space Development capabilities in Latvia and Estonia illustrates different directions of Mass Customization implementation in digital platforms but also reveals common interest and primary focus on external processes and endusers, their experience management, encouragement of co-creation and co-design activities in the insurance-specific value chain. In the case of Lithuania, more balanced but a low widespread existence of key Mass Customization capabilities is noticed. The leading capability of Robust Process Design indicates that insurance organizations now are more focused on internal Mass Customization process management, digital resources, and product analysis.

Research results refer to the assumption that neither the Mass Customization concept and its capabilities nor the combinations with digital solutions and Mass Personalization concepts are yet sufficiently widespread within the analyzed online sales platforms of the non-life insurance market in Baltic countries.

\section{REFERENCES}

Albrecher, H., Bommier, A., Filipović, D., KochMedina, P., Loisel, S. \& Schmeiser, H. (2019). Insurance: Models, Digitalization, and Data Science. SSRN Electronic Journal, 19-26, 1-3. doi: 10.2139/ssrn.3382125 Retrieved from: https://papers.ssrn.com/sol3/papers.cfm?ab stract_id=3382125

Baležentis, A. \& Žalimaitè, M. (2011). Ekspertinių vertinimų taikymas inovacijų plètros veiksnių analizèje: Lietuvos inovatyvių imonių vertinimas, Management theory and studies for rural business and infrastructure Development, 3(27), 23-31. ISSN 1822-6760, 2345-0355 https://www.lituanistika.lt/content/31060

Baranauskas, G. (2021). Application of customization and personalization in digital solutions of non-life insurance market: a case study of Lithuanian, Latvian and Estonian e-sales platforms. Engineering Management in Production and Services, 13(2). doi: 10.2478/emj-2021-0013

Baret, S., Celner, A., O'Reilly, M. \& Shilling, M. (2020). Finance and the future of IT Funding innovation at the speed of agile. Deloitte Insights, 1-20.

https://www2.deloitte.com/us/en/insights/f ocus/tech-trends/2020/future-of-it-andfinance-funding-innovation-at-the-speedof-agile.html

Bohnert, A., Fritzsche, A. \& Gregor, S. (2019). Digital agendas in the insurance industry: the importance of comprehensive approaches. Geneva Pap Risk Insur Issues Pract 44, 1-19. doi: https://doi.org/10.1057/s41288-018-0109-0. https://www.researchgate.net/publication/3 28173678_Digital_agendas_in_the_insuranc e_industry_the_importance_of_comprehens ive_approaches

Cappiello, A. (2018). Technology and Insurance. In Cappiello, A., Technology and the insurance industry. Re-configuring the competitive landscape (p. 7-28). In Palgrave Pivot, Cham. doi: 10.1007/978-3-31974712-5

Chang, S., Survant, L., Walch, D. \& Woo, R. (2020). Confronting the crisis: How financial services firms are responding to and learning from COVID-19. Deloitte Insights, 1-18.

https://www2.deloitte.com/us/en/insights/f ocus/tech-trends/2020/future-of-it-andfinance-funding-innovation-at-the-speedof-agile.html

Daaboul, J., Bernard, A. \& Laroche, F. (2012). Extended value network modelling and simulation for mass customization implementation. J Intell Manuf, 23, 2427 2439. doi: https://doi.org/10.1007/s10845010-0493-1 https://www.researchgate.net/publication/2 21030190_Extended_Value_Chain_Modellin g_and_Simulation_for_Mass_Customization 
_Implementation

El Arif, F.Z. (2020). Insurance Distribution in the Digital Age. IOSR Journal of Economics and Finance (IOSR-JEF), 11(3), 31-38. doi:10.9790/5933-1103063138 Retrieved from: https://www.iosrjournals.org/iosrjef/papers/Vol11-Issue3/Series6/E1103063138.pdf

Eling, M. \& Lehmann, M. (2018). The Impact of Digitalization on the Insurance Value Chain and the Insurability of Risks. Geneva Papers on Risk and Insurance - Issues and Practice, 43, 359-396. doi: 10.1057/s41288-0170073-0

https://www.researchgate.net/publication/3 21636110_The_Impact_of_Digitalization_on _the_Insurance_Value_Chain_and_the_Insur ability_of_Risks

Etikan I. \& Bala K. (2017). Combination of probability random sampling method with non-probability random sampling method (sampling versus sampling methods). Biometrics \& Biostatistics International Journal, 5(6), 210-213. doi: 10.15406/bbij.2017.05.00148 Retrieved from:

https://medcraveonline.com/BBIJ/BBIJ-0500148.pdf

Goepel, K. D. (2019) Comparison of Judgment Scales of the Analytical Hierarchy Process A New Approach. International Journal of Information Technology \& Decision Making, 18(2), 445-463. doi:

https://doi.org/10.1142/S021962201950004 4

Gómez, F. G., Gómez, M. D. P. M. \& Gans, A. G. (2012). Fuzzy Logic Techniques (FLT) in the Interpretation of the Responses Given to a Questionnaire Filled out by Professors in Spain. International Journal of Humanities and Social Science, 2(20), 23-36. Retrieved from:

https://core.ac.uk/download/pdf/19719086. pdf

IAIS (2018). Issues Paper on the Increasing Use of Digital Technology in Insurance and its Potential Impact on Consumer Outcomes. https://www.iaisweb.org/file/75985/issuespaper-on-the-increasing-use-of-digitaltechnology-in-insurance-and-its-potential- impact-on-consumer-outcomes

Kamis, A., Stern, T. \& Ladik, D. M. (2008) A flowbased model of web site intentions when users customize products in business-toconsumer electronic commerce. Information Systems Frontiers, 12, 157-168. doi:https://doi.org/10.1007/s10796-0089135-y https://www.researchgate.net/publication/2 20199012_A_Flow-

based_model_of_web_site_intentions_when _users_customize_products_in_business-toconsumer_electronic_commerce

Klapkiv, L. \& Klapkiv, J. (2017). Technological innovations in the insurance industry. Journal of Insurance, Financial Markets and Consumer Protection, 26(4), 67-78. https://depot.ceon.pl/bitstream/handle/123 456789/14333/RU265.pdf? sequence $=1$ \&isAllowed $=y$

Klapkiv, Y., Lyubov, K. \& Zarudna, N. (2018). Online Distribution of Insurance of Civil Liability of Owners of Vehicles, The Experience of Poland, Opportunities of Ukraine. Baltic Journal of Economic Studies, 4. 195-201. doi: 10.30525/2256-0742/20184-1-195-201. Retrieved from:

http://www.baltijapublishing.lv/index.php/i ssue/article/view/351/pdf

Libby, R. \& Blashfield, R. K. (1978). Performance of a composite as a function of the number of judges. Organizational Behavior \& Human Performance, 21(2), 121-129. doi: https://doi.org/10.1016/00305073(78)90044-2

Łyskawa, K., Kędra, A., Klapkiv, L., \& Klapkiv, J. (2019). Digitalization in insurance companies. Paper presented at International Scientific Conference "Contemporary Issues in Business, Management and Economics Engineering", Vilnius, Lithuania. doi: https://doi.org/10.3846/cibmee.2019.086 http://cibmee.vgtu.lt/index.php/verslas/201 9/paper/view/500

Mitrovic, D., Trifunovic, D. \& Ranđelović, S. (2019). Digitalisation in the Financial Sector and Implications for Insurance. In: Contemporary Trends In Insurance At The Beginning Of The Fourth Industrial Revolution. Publisher: Faculty Of Economics, 
from:https://www.academia.edu/39238622/ Digitalisation_in_the_Financial_Sector_and_ Implications_for_Insurance

Mustafina A. A., Kaigorodova G. N., Alyakina P. D., Velichko N.Y. \& Zainullina M.R. (2020)

Digital Technology in Insurance. In: Ashmarina S., Mesquita A., Vochozka M. (eds) Digital Transformation of the Economy: Challenges, Trends and New Opportunities. Advances in Intelligent Systems and Computing, vol 908. Springer, Cham. https://doi.org/10.1007/978-3-03011367-4_65

Nicoletti, B. (2016). Innovation in Insurance. In Nicoletti, B. Digital insurance: business innovation in the post-crisis era. UK: Palgrave Macmillan. https://doi.org/10.1057/9781137553270

Piller, F. T., Thorsten, H., Ihl, C. \& Salvador, F. (2014). Strategic Capabilities of Mass Customization Based E-Commerce: Construct Development \& Empirical Test. Paper presented at the 2014 47th Hawaii International Conference on System Sciences, Waikoloa, HI, USA, January 6-9, doi:10.1109/HICSS.2014.403. https://ieeexplore.ieee.org/stamp/stamp.jsp ?tp=\&arnumber $=6759005$

Podvezko, V. \& Sivilevičius, H. (2013) The use of AHP and rank correlation methods for determining the significance of the interaction between the elements of a transport system having a strong influence on traffic safety. Transport 28(4): 389-403. doi:https://doi.org/10.3846/16484142.2013. 866980

Podvezko, V. (2005). Agreement Of Expert Estimates. Technological And Economic Development of Economy, 11(2), 101-107. Doi:https://doi.org/10.3846/13928619.2005. 9637688

Porter, M. (1985) The Competitive Advantage: Creating and Sustaining Superior Performance, New York: The Free Press. https://www.albany.edu/ gs149266/Porter\% 20(1985)\%20-\%20chapter\%201.pdf

Quir'os, P., Alonso, J. M. \& Pancho, D. P. (2016) Descriptive and Comparative Analysis of Human Perceptions expressed through Fuzzy Rating Scale-based Questionnaires.
International Journal of Computational Intelligence Systems, 9(3), 450-467. Doi: https://doi.org/10.1080/18756891.2016.117 5811 Retrieved from: https://www.atlantispress.com/journals/ijcis/25868704

Rattanalertnusorn, A., Thongteeraparp, A. \& Bodhisuwan, W. (2013). Fuzzy Rating Score on the Likert Scale. Paper presented at International Conference on Engineering and Applied Science (ICEAS 2013) Osaka, Japan.

Risdiyono, R., Imam D. W. \& Affan M. (2016). Mass Customization and Personalization Prospects in Developing Country: Indonesian Context. IOP Conference Series: Materials Science and Engineering 105: 1-5. doi:10.1088/1757-899X/105/1/012046. https://iopscience.iop.org/article/10.1088/1 757-899X/105/1/012046

Saaty, T. L. (2008). Decision making with the analytic hierarchy process. Int. J. Services Sciences, 1(1), 83 - 98. doi:10.1504/IJSSCI.2008.017590

Salvador, F., Holan, P. D. \& Piller. F. T. (2009). Cracking the Code of Mass Customization. MIT Sloan Management Review, 50(3), 7179. https://www.researchgate.net/publication/2 65498057_Cracking_the_Code_of_Mass_Cus tomization

Schilirò, D. (2020). Towards Digital Globalization and the Covid-19 Challenge. International Journal of Business Management and Economic Research (IJBMER), 11(2), 1710-1716. Retrieved from: https://www.researchgate.net/publication/3 41408390_Towards_Digital_Globalization_a nd_the_Covid-19_Challenge

Shubenko, I.A. (2020). Trends of Digitization in the Insurance Market of Ukraine. Business Inform, 2(505), 273-279. doi: 10.32983/2222-4459-2020-2-273-279 https://www.researchgate.net/publication/3 41158739_Trends_of_Digitization_in_the_In surance_Market_of_Ukraine

Stoeckli, E., Uebernickel, F. \& Brenner, W. (2016). Digitalization in the Insurance Industry. Themes and Decisions That Matter: Insights from a Multiple-Case Study in Germany and Switzerland. Series on 
Research in Information Systems

Management and Business Innovation, 6.

Stoeckli, E., Dremel, C. \& Uebernickel, F. (2018).

Exploring characteristics and

transformational capabilities of InsurTech

innovations to understand insurance value creation in a digital world. Electronic

markets, 28, 285-307. doi:

https://doi.org/10.1007/s12525-018-0304-7

Vonglao, P. (2017). Application of fuzzy logic to improve the Likert scale to measure latent variables. Kasetsart Journal of Social Sciences, 38, 337-344. doi:

https://doi.org/10.1016/j.kjss.2017.01.002

https://www.sciencedirect.com/science/arti cle/pii/S2452315117303739

Warg, M., Zolnowski, A., Frosch, M. \& Weiß, P. (2019). From Product Organization to Platform Organization - Observations of Organizational Development in the Insurance Industry. Paper presented at conference: The 10 years Naples Forum on Service - Proceeding, Ischia, Italy, 2-16. https://www.researchgate.net/publication/3 34327827_From_Product_Organization_to_ Platform_Organization__Observations_of_Organizational_Developm ent_in_the_Insurance_Industry

Weingarth J., Hagenschulte J., Schmidt N. \& Balser M. (2019). Building a Digitally Enabled Future: An Insurance Industry Case Study on Digitalization. In: Urbach N., Röglinger M. (eds) Digitalization Cases. Management for Professionals. Springer, Cham. doi: https://doi.org/10.1007/978-3319-95273-4_13

Wiesböck, F., Matt, C., Hess, T. H., \& Li, L. (2017). How Management in the German Insurance Industry Can Handle Digital Transformation. Management Report, 1-26. Retrieved from: https://www.wim.bwl.unimuenchen.de/download/epub/mreport_201 7_1.pdf

Zarina, I., Voronova, I. \& Pettere, G. (2019). Internal model for insurers: possibilities and issues. Paper presented at International Scientific Conference Contemporary Issues In Business, Management and Economics Engineering'2019, Vilnius, Lithuania. doi: 10.3846/cibmee.2019.026.
Zolnowski, A. \& Warg, M. (2017). Let's Get Digital: Digitizing the Insurance Business with Service Platforms. Cutter Business Technology Journal, 30(9), 19-24.

\section{ABOUT THE AUTHORS}

Gedas Baranauskas, email: gedasbaranauskas@mruni.eu

Gedas Baranauskas is a PhD student at Institute of Leadership and Strategic Management, Mykolas Romeris University, Lithuania. Gedas Baranauskas has a scientific interest in Mass Customization and Personalization concepts; Digital Platforms Business models; Insurance digitalization, combined management, and IT methods. On a daily basis he is an IT business analyst and project manager at one of the leading insurance companies in the Baltics.

Dr. Agota Giedrė Raišienė is the Professor of Management at Mykolas Romeris University, Lithuania. Raišienè's current research interests center on Organization management, Inter-sectorial collaboration, Leadership, and Telework issues. She has authored and co-authored numerous research articles as well as some monographs and textbooks. Also, she is a President of Academic Association of Management and Administration and serves as business consultant at LLC Bridge2Apex. 